\title{
THE FORGOTTEN MEME. ON THE EXAMPLE OF LIFE AND WORKS OF PLACYD JANKOWSKI
}

\section{PATRYK CHŁOPEK}

ABSTRACT Placyd Jankowski (known also as John of Dycalp) was a popular writer active in the 1840s, he quickly gained popularity thanks to his humorous lyrics, but before his death in 1872 he was almost forgotten by readers. This raises questions about the rules guiding cultural memory. One of the concepts that could explain the process of cultural heredity is the memetic theory proposed by Richard Dawkins. The scholar assumes the existence of cultural units subject to the process of evolution, which he called memes. Their success and survival depend on the fulfillment of specific characteristics to which the human mind is particularly susceptible, i.e. topicality, originality, narrative, and universality. Using the tools developed by memetics, the article will attempt to describe the reasons for social forgetting on the example of the life and work of Placyd Jankowski.

KEY WORDS Placyd Jankowski, $19^{\text {th }}$-century literature, memetics, cultural memory, forgetting

CONTACT Nicolaus Copernicus University in Toruń; patryk.chlopek@gmail.com 
When analyzing artists' motivations when creating their works, apart from the need for self-realization or presenting a thought, idea, or philosophy, it is worth mentioning the desire to imprint oneself in the recipients' memory. Appropriate adjustment to a given group's interests may contribute to modeling not only its social awareness but also its valuation, empathy, or morality. When thinking about great works (such as Master and Margarita, Mona Lisa, Eine Kleine Nachtmusik) we have no doubt that they are firmly established in our culture (in a broad global aspect), that they have exerted and still exert influence on individuals interested in culture. However, what is more important is that those people who do not consciously make use of cultural heritage, do not read books, do not go to art galleries, and do not listen to classical music will nevertheless recognize certain elements originating from famous works of art, which we could define as the determinant of being "established in culture". Is it possible to forget such widespread works or such famous authors? Probably not in the case of works of art of global range, but in the regional range it can occur.

Placyd Jankowski (John of Dycalp), despite many years of an active and successful career in the field of Polish literature, for some reason ceased to influence the readers' imagination, being forgotten even during his lifetime. It is an interesting case in terms of the process of social forgetting and its reasons. On the one hand, the state of affairs in which obsolete content is replaced by more up-to-date content is purely intuitive and understandable, but not always is the out-of-date content forgotten. It may be important to ask what determines the process of forgetting and how the selection of forgotten elements is made.

The process of forgetting the elements of culture (including a literary work) seems possible to describe employing Darwin's theory of evolution, which was used by biologist Richard Dawkins in 1976 in his book entitled The Selfish Gene to create the theory of memetics, assuming the existence of units of culture which he called memes. He decided that another level of the evolutionary game has developed in our minds, in which the most important element is the cultural message. Probably the best example of cultural evolution is the development of language taking place without the participation of the biological equivalent of a meme - a gene. This process takes place without any changes in the human genotype, which is proved, among other things, by the speed of transformation ahead of the development possibilities of biological units. This may be an argument for considering non-biological ways of evolution - in this case, cultural evolution.

\section{$1 /$ THE THEORY OF MEMETICS}

Dawkins claims that "when we die there are two things we can leave behind us: genes and memes" (Dawkins 2006: 199). A meme, analogically to a gene, is a replicator - which means it multiplies certain information by transmitting it further. Richard Brodie believes this unit to be a universal key, "the secret code of human behavior, a Rosetta stone finally giving us the key to understanding religion, politics, psychology, and cultural evolution" (Brodie 2009: 4). Fashion, culinary traditions, ceremonies, customs, art, architecture, or technology - cultural units may take various forms: "Examples of memes are tunes, ideas, catch-phrases, clothes fashions, ways of making pots or of building arches" (Dawkins 2006: 192).

The interest enjoyed by the concept of a meme has led to the creation of numerous definitions adjusted to the needs of different fields of science. According to neurobiologist Marek 
Kaczmarzyk "today, when we want to use the term, we must define it for our own, local use" (Kaczmarzyk 2018: 106). One of the most universal descriptions of the term can be considered the one formulated by Glenn M. Grant in his Memetic Lexicon: "[It is] a contagious information pattern that by parasitically infecting human minds and altering their behavior, causing them to propagate the pattern [...]. An idea or information pattern is not a meme until it causes someone to replicate it, to repeat it to someone else or otherwise exposes someone to infection" (Grant 2005: 73). The place of residence for memes, which function in the form of connections between neurons, are our minds. Their transmission, also called replication, takes place by formulation of a language statement, transmitted further through the process of exchanging information in a lasting form (text) (Borkowski - Nowak 2005:47) and (predominantly) through imitation:

Take the song 'Happy Birthday to You'. Millions of people - probably thousands of millions of people the world over - know this tune. Indeed, I only have to write down those four words to have a pretty good idea that you may soon start humming it to yourself. Those words affect you, probably quite without any conscious intention on your part, by stirring up a memory you already possess. And where did that come from? Like millions of other people you have acquired it by imitation. Something, some kind of information, some kind of instruction, has become lodged in all those brains so that now we all do the same thing at birthday parties. That something is what we call the meme (Blackmore 1999: 7).

According to Dawkins, between units of culture there is certain type of rivalry (Dawkins 2006: 197). The human mind has become a target for memes, of which, similarly to Darwin's theory, only the strongest "specimens" will be able to count on the extension of their existence through replication - a transmission to the next generation of human carriers (hosts) in a process of broadly understood imitation (Dawkins 2006: 197). In the scientific community, good ideas displace worse ones. This works on the basis of long and detailed research and discussions based on methodological assumptions and paradigms. In the literature, however, it is more difficult to objectively assess what can be successful for the reader. What really determines a meme's vitality? The memetic theory was created on the basis of so-called Universal Darwinism, which assumes that we are dealing with evolution every time we are able to distinguish three phenomena: 1 . hereditariness involving transmission of features, 2. adaptation-supporting changeability, and 3. selection (Wężowicz-Ziółkowska 2015: 138-149), which in the context of forgetting will be crucial for us. As Susan Blackmore points out, memes correspond to this model, thanks to which we can consider them as fully-fledged units subject to the evolutionary algorithm of the individual: their hereditariness (preservation) is achieved by imitation; variability can be clearly observed even in the event of the development of language; finally, the memetic selection depends on whether a given unit attracts our attention - in other words, whether it is attractive to us (Blackmore 1999: 14).

What then makes a meme attractive for us? The human mind is particularly susceptible to information that has specific characteristics - timeliness, originality and narrative. Such a description includes, among other things, a gossip which, however, despite rapid expansion, loses (usually) its durability because at least one of its characteristics (topicality) is limited. Dawkins explains the extraordinary possibilities of meme's survival on the example of God: 
What is it about the idea of a god that gives it its stability and penetrance in the cultural environment? The survival value of the god meme in the meme pool results from its great psychological appeal. It provides a superficially plausible answer to deep and troubling questions about existence [...] God exists, if only in the form of a meme with high survival value, or infective power, in the environment provided by human culture (Dawkins 2006: 193).

Taking into account these voices, it should be considered that a meme has the greatest potential for replication at a time when it is not only topical, narrative and original, but also has the potential to influence the imagination and feelings of the audience in a wider perspective - not only in the individual but also in the collective context. The more universal the meme is, the more likely it is to survive ${ }^{1}$.

The main reason for the process of forgetting should, therefore, be seen first of all in the progressive weakening of meme by blurring its originality and disappearance of its relevance, and then in its inadequacy to the needs of a wider audience, which would allow for replication despite the weakening of other characteristics.

\section{2 / MEMES IN LITERATURE}

The matter which should be first stated is the distinction between a meme and a cultural text, which is a significant product of culture, "internally organized according to specific rules" (Kostkiewiczowa 2005: 574-575). A meme rather performs a representative function, is a mental link which emerges after assimilation of the text (meaning its replication). A text exists in extra-sensory terms and may be a result of mutual influences between numerous memes in an author's mind, with the meme itself being a mental being, which exists thanks to interaction between the recipient and the text.

We should also consider whether Dawkins' theory can be applied to literature research. Some memeticians do not agree on what we can consider as memes. From Brody's point of view, our knowledge as a whole (even if we have acquired it by other means than imitation) consists of memes (Brodie 2009: 128-129), Blackmore, on the other hand, believes that "as long as the behavior cannot be transmitted through imitation, it does not become a meme". The scholar considers the replicative properties to be crucial - the behavior developed on the basis of instrumental conditioning will not be such an entity, because it was not copied, but developed by trial and error. For example - cycling skills will not be a meme, because the motor coordination cannot be copied, one can only work it out (Blackmore 1999: 42-46). What is more, the reflexes which are a manifestation of the so-called social infectivity are not meme either. Although yawning, laughing, and even directing our gaze to the point observed by other people at first glance may look like a sign of imitation, they are, in fact, based on sensitivity to a given stimulus to which our copied reaction is inborn, not acquired (Blackmore 1999:47-48).

Creativity of any kind can also be considered a meme, if, according to Blackmore, it is replicated by our mind. Humming of the melody, evoking of a painting seen at a museum in

1 Dawkins also points out that a meme, analogously to the gene, gains or loses the ability to replicate depending on the fidelity of copying, fertility (number of copies made) and longevity (the longer a copy of meme survives, the greater the chance of its further replication). 
the memory and describing it can be considered as a manifestation of replication ${ }^{2}$, on the same basis after reading a literary work we can outline its plot. By humming, we imitate (replicate) a previously heard melody, just like while describing the plot or the main thought of a book we can imitate the author's train of thoughts. ${ }^{3}$ However, a problematic question remains, which Blackmoore also raises: "Is Beethoven's Fifth Symphony a meme, or only the first four notes?" (Blackmore 1999: 53).

Dawkins considers the particularly distinctive part of a composition to be a single meme. Such an interpretation of a meme could be extremely problematic, as it seems that it could only refer to musical pieces. We can distinguish elements representative of some of the works, such as spilling oil by Anne in Master and Margarita, but these individuals may not be properly replicated, or remembered, by those who do not know the work due to the lack of a wider context. Returning to the aforementioned definition by Grant, we read that "an idea or pattern of information is not a meme until it makes someone replicate it, repeat it to someone else, or otherwise expose someone to infection". This is in line with Blackmore's concept, which also reflected on the figure of a single meme:

A single word is too short to copyright and an entire library too long, but we can and do copyright anything from a clever advertising jingle to a 100000 -word book. Any of these can count as memes - there is no right answer to the question - 'What really is the unit of the meme' (Blackmore 1999: 54).

According to the scholar, a single literary work can, therefore, be considered a meme. However, the problem may be its further replication, because we will not (usually) be able to convey the content of the book word for word, describing at best the plot, literary motives or interpreting the work. Nevertheless, the meme will be heavily distorted in comparison with the original text.

However, memes connected with creativity could take different forms - assuming that by convincing someone of the great talent of a given writer, we will pass on information that has a chance to be reproduced in other people's minds much more easily. Imprinting this thought on a potential reader, we can convince them to reach for the artist's work and spread the thought further or, if it does not meet expectations, create the opposite one. In this way, we can consider both a complete work and the figure of the author as a meme, or more precisely, to associate them with a particular emotion "good writer", "bad writer" and "good book", "bad book". Separate memes can be individual motifs and patterns related to building a plot or character trait, not only interesting for readers but also reproduced by other authors. They can also be single sentences or words, which will then constitute a kind of reference to the works from which they come. The form a meme will take ultimately depends on whatever attracts the attention of a recipient of a literary work.

2 Although in this case, one should consider whether for the person to whom we present a given image, a meme will be the image of it created in their mind, or our description.

3 The use of the term "imitating" in the context of cultural message is also a debatable matter, which Dobrosława Wężowicz-Ziółkowska discusses more broadly in his article: D. Wężowicz-Ziółkowska, 2014, Jednostki pamięci kulturowej. Próba kulturoznawczej redefinicji i interpretacji hipotezy memetycznej, "Teksty z Ulicy. Zeszyt Memetyczny" 15, pp. 11-26. 
To sum up, in accordance with the previous assumptions, a meme's extinction is connected with the progressive reduction of the influence on the recipients; a cultural unit plays an increasingly less significant role in the society due to the lack of demand for its transmission. Potential "carriers" may also fail to assimilate it, due to the overflow of similar or stronger cultural units (more recent and/or more qualitative). As a result, meme replication is made more difficult.

This does not, of course, determine a total death of a meme. It can return just like the hieroglyphs, which were a regular system of language recording in ancient Egypt, forgotten after the fall of civilization, unused for thousands of years, so that modern archaeologists can learn to read them again, thus bringing the meme back to life. Even nowadays, thanks to the existence of libraries, archives, and electronic media, many of the memes that are not in circulation can be brought back to life through texts stored in these places, such as the works by Placyd Jankowski.

\section{3 / PLACYD JANKOWSKI}

Well-known in the '40 and '50s of the $19^{\text {th }}$ century, the author of over twenty publications, an initiator of original at that time artistic projects, even before his death in 1872 had become almost completely forgotten by readers. The reasons for such a dynamic deterioration of the meme can be searched for in the writer's biography and works.

The author was a character whose reception was ambivalent, both due to his works, and his life decisions. On the one hand, he was a delicate ${ }^{4}$, gentle man, who devoted time to his family. It is mentioned by, among others, Walerian Charkiewicz (1928: 7) and Aleksander Walicki (1888: 470). On the other hand, he had to struggle with a bad reputation all his life, sometimes unjustly. He was often mistaken for his brother, Jan Jankowski, the anti-hero of the Philomaths' process. The case was reproached to him even after his death, among others by Stanisław Tarnowski (1888: 586), which might have had an influence on the reception of Placyd's works. Due to the act of apostasy and conversion to Orthodox Church in 1837, in some circles he was considered a traitor, the reason why he was referred to without leniency by priest Stanisław Chołoniewski (Charkiewicz 1928: 46-47). Indeed, Jankowski's contribution to the Russification movement was noticed, and after his death, it was mentioned in the press even for frequently ${ }^{5}$ rather due to his participation in the liquidation of the Greek Orthodox Church than because of the works he had written in his lifetime. However, as argued by Walerian Charkiewicz, "let us not be too surprised: Siemaszko (Józef Siemaszko, 1798-1868, Orthodox bishop responsible for the movement which led to the liquidation of the Greek Orthodox Church - note by P. Ch.)

$4 \quad$ In his work Autopopobiografia (Autopopsbiography) he wrote about himself as follows: "Baby's first two words are usually listened to most carefully, and rightly so. Those mechanically repeated sounds Papa or Mama, so easily explained by grammarians, obviously contain a bigger mystery than the humiliating conclusion that a human being is an imitating species [...]. The word Mama states that a baby is created to more gentle feelings, impenetrable to evil, even when tempted so by the power of their nature; capable of only single beautiful actions, but not to the whole of thusly named great deeds; superstitious, fearful and blindly trusting its consciousness, Carol XII, Pitt, and Napoleon undoubtedly named their fathers first. I, with my first word, made my mother tender". P. Jankowski, 1841, Autopopobiografia. Pisma przed-ślubne i przed-splinowe, vol. 1, Vilnius, pp. 48-49.

5 Especially at the beginning of the $20^{\text {th }}$ century. 
with the power of his immense individuality subdued everybody into submission, running his game very skillfully, not speaking definitively and creating the illusion of great, glorious future for the church". The project of changing the Greek Orthodox Church by Józef Siemaszko actually led to the liquidation of that formulary, resulting in, among others, incorporation of the liquidated cult's clergy into the Russian Orthodox Church. "What stance did Placyd Jankowski take? Was he an active liquidator of the Greek Orthodox Church, an enemy of all that is Catholic and Polish? Was he a victim of family relationships and did not know what the results will be of the effort made by the powerful bishop and the whole consistory? All of those questions can be equally convincingly answered both 'yes' and 'no'...' - writes Charkiewicz (1928: 20). According to the scholar, on the one hand, the writer could not have known what was going on in Greek Orthodox circles and what the role of priest Siemaszko was in all of that, on the other, however, Jankowski might have been driven by ecumenical ideas, neither was he a careerist: "His character was to righteous and peaceful, he never showed urge to gain glamour or riches" (Charkiewicz 1928: 20). Despite all that Jankowski finally embraced the Orthodox religion and "converted" former Greek Orthodox priests to it - very effectively, as it turns out, which is evidenced by the trust of the future bishop of Lithuania.

During the synod in Połock, on 12 February 1839, the act of unification of Greek Catholic Church with the Orthodox Church was signed (Mironowicz 2005: 13). From that time on, Jankowski was focusing on the work of a clerical dignitary. Residing in Żyrowice and Vilnius, he has earned the reputation of an erudite, a devoted clergyman, who ably did what was expected from him, receiving many awards in recognition of his services (Charkiewicz 1928: 25-26). Due to health reasons, after a merely 2-year stay in Vilnius, he received the parish of Białawicze village. He spent over ten years there, which for him was the period of "gradual distancing from the world" (Charkiewicz 1928:32). In 1858, at the age of 48 , he retired to Żyrowice. He did not publish any more books, and many years earlier he had started to lose his readership. After the fall of the January Uprising, when he returned to his journalistic work for a short time, he was approached by representatives of the Russian periodicals "Wilenskiy Vyestnik" and "Litovskiy Yeparchy Vedomosti". In the articles from that period, Jankowski appears as an enemy of Polishness and Catholicism with a sentimental attitude towards his student years. We can only suspect what the motivations for such a diametrical change in the writer's rhetoric were, but it seems justified to assume it was the influence that this had on preserving the memory of the writer and his works. Moreover, taking into account the domination of biography in literary research at the beginning of the 2oth century, Jankowski may have been deliberately downplayed by literary researchers. Also, a monograph on the writer, written in 1928, is not as much focused not on Jankowski's works, but rather on his participation in the disintegration of the Greek Catholic formulary.

Such an approach may be perceived as harmful, because it does not take into account Jankowski as a man who, after surviving the January Uprising, could simply be afraid of the invader. Gentle by nature, submissive, and thinking primarily about the well-being of his family, Jankowski acted in accordance with the requirements of his situation at the time, thus wanting to ensure a peaceful life for himself and his loved ones. "He strived for a home, for a peaceful and cheerful life surrounded by friendly and cordial people" (Charkieiwcz 1928: 21). That is why he was humbly working for a more influential clergyman, and why he did not touch upon political topics in his works. 
In 1867, Jankowski's wife died as a result of the news of the death of their son, who went to Russia to study. After this tragedy, Placyd decided to live in seclusion, limiting any contact with the world to a minimum. Józef Orda, who personally knew the writer, described the former clergyman in an interview with Walerian Charkiewicz in the following words: "Jankowski was an extremely educated man, he wrote a lot, had a sharp pen, and in his conversations he often expressed his regret that he had been dragged into the whole affair of Greek Orthodox Church liquidation". Jankowski died in 1872, almost completely forgotten, which is somewhat confirmed by Józef Ignacy Kraszewski, the writer's close friend, in an obituary written after more than a year, who remarked that "the news of his death did not reach us betimes" (Kraszewski 1873: 293).

This uncertainty connected with the figure of Jankowski, the phantom of a traitor of the nation, a Russificator, an apostate - all this, although not fully corresponding to reality, could have had a significant impact on the reception of Jankowski's work and could have been a factor that discouraged the audience from assimilating his works, which certainly also contributed to limiting the possibility of replicating the memes associated with them.

It should be noted, however, that Jankowski's life decisions do not have to be the main reason for the regression of the interest in his work. The writer, under the pseudonym of John of Dycalp, started his intensive work as an artist four years after the act of apostasy and although he may have been controversial, the best period of his work is considered to be the 1840's, especially the first half of them.

Jankowski came to create in times he could not adapt to. The polish emigration literature was dominated by political subjects related to national liberation; on the other hand, those who were under strict censorship control considered it their mission to "awaken the mental movement". This was the time when writers had to struggle with the responsible task of maintaining the memory of Polishness and the motivation to fight the invader. "Patriotic motifs in poetry were not only fashionable, but also binding; the power of patriotic feeling often determined the readability of a work; the lack of similar motifs was considered to be something reprehensible, unacceptable, worthy of strong contempt" (Charkiewicz 1928:39) - as vividly described by Walerian Charkiewicz.

Placyd did not share those beliefs. The reader will not find political topics in his works. His artistic career indicates that was distancing himself from the Romantic convention, at times going as far as ridiculing it. One such example is Rozmowa duchów (Dialogue of spirits) from the collection entitled Pisma przed-ślubne i przed-splinowe (Pre-marriage and pre-spleen writings) (Jankowski 1841:3-26). Jankowski tries to trivialize there the topos of unreturned love, which from his perspective could be an overused motif. He also has no patience for the poetry created at the time, stating that he would rather "listen to the grass grow" than read it (Jankowski 1843:

6 Józef Ignacy Kraszewski wrote to Placyd Jankowski in a letter from 20 April 1841: "I do not believe in literary immortality and do not care much about fame; I wish to, with my writings, example, shouting, beating, etc. bring into motion, move, encourage, to open roads for others, spread a few ideas which roam around my head. It is my goal, it is the fame I desire- the fame of an inspirer [...] It is only about encouraging, about motivating to work. Having opened one road, I leap to another, I write and live in such a manner, and I desire that someday someone says about me only that, and that I contributed to the revival of the thinkers' movement in my time". Quote after: W. Charkiewicz, 1928, Placyd Jankowski (John of Dycalp). Życie i twórczość, Wilno, p. 40. 
176). Nevertheless, he carefully avoided a firm attitude in any respect, allowing himself only subtle, humorous hoaxes. His distanced approach to social life could also have been a reason for not taking up the subject that was expected from the creators of this generation. Political and national liberation issues, as well as historical ones, remained for Jankowski an area which he clearly did not want to enter. However, he was left with loose humor and folklore, which could have been the reason for his initial readership.

Due to the excess of certain content, the solutions proposed by John of Dycalp may have been alluring due to their freshness and interesting form. Apart from that, readers could count on homely and moral character of his works. According to Charkiewicz: "It was enough for modest readers, under the care of government censorship, to applaud the author, as not merely a champion of Polishness, and use those faint and shy images of the Polish life to draw comfort and faith in the strength and vitality of the nation for themselves" (Charkiewicz 1928: 44). With his first publications, Jankowski began to be considered a promising author, his "John of Dycalp" meme quickly spread in the minds of readers due to its originality.

Paradoxically, what initially ensured Jankowski's readership may also have been the reason why the works of art were not preserved. The price for the originality of the works was their universality - the lack of elevated content, focus on idyllicism and folklore was what allowed the readers to breathe, cut themselves off from the difficult reality of life under the Russian occupation, it was a breath of fresh air in the literature of the 1840s. At the same time, however, when the humor of these works lost its relevance, they lacked arguments that would determine its establishment in the cultural circulation.

Jankowski was an extremely active writer, but his readers realized that he did not possess an extraordinary talent. Apparently, he "was not a brilliant talent, but had some virtues which not every, even extraordinary, writer possesses" (Walicki 1888:471). He published his first book, entitled Chaos, in 1835 under the alias of 'Witalis Komu-Jedzie' and received positive reviews for it, mainly due to its original form and humorous touch. He did not, however, ride that wave, and waited as long as six years until he published his next work - Pisma przed-ślubne i przed-splinowe. The book, published already under the alias of John of Dycalp, is very similar to previously published Chaos, but the development of the author's literary awareness is clearly visible.

After the first two books, characterized by a multitude of forms, genres and conventions, cooperation with Józef Ignacy Kraszewski on Powieść składana (A folded novel) earned Jankowski a reputation of a literary experimenter ${ }^{7}$. The joint project raised considerable interest of the literary community, possibly mostly due to Kraszewski's participation. Unfortunately, the book failed to meet the readers' expectations and faced severe criticism, which the authors responded to with understanding, since as Kraszewski reminisces: "We were both rather dissatisfied with it; the writing took too long, and the idea itself was unfortunate" (Kraszewski 1873: 311).

7 As written (before the publication of Powieść składana) by Michał Grabowski to Placyd Jankowski: "With a few works, you have made all of us turn our eyes on you; everybody recognizes you as a writer of a type completely unknown in our literature; hence they pay utmost attention to your future works and I, driven by my critical dedication, have the duty to express this opinion of the generality". Quoted after: W. Charkiewicz, 1928, Placyd Jankowski (John of Dycalp). Życie i twórczość, Wilno, p. 48. 
The' 40 s were, in general, the best period for Jankowski's literary development, but already in the second half of the decade he started to lose his zeal for writing. During that time, he was also a member of the so-called "weekly coterie", which was the editorial board of literary criticism department of a Catholic "Tygodnik Petersburski". It is interesting, due to the fact that the author of Chaos was already an apostate and an Orthodox Chuch convert. In this context, starting cooperation with the weekly seems intriguing, and may also indicate author's little care for ideological matters.

Being a member of the Coterie earned Jankowski several flattering reviews of his works. Henryk Rzewuski admonished Michał Grabowski in the following way: "But why has he yet not made a mention of 'Pre-marriage and pre-spleen writings' and not enlightened the readers that there is already a new, completely national Stern, often equal to him in wit, and at times almost equal in feeling". ${ }^{9}$ On the pages of "Tygodnik Petersburski" there were sometimes overly flattering reviews presenting Jankowski as an apparition and an outstanding artist. In opposition to the voices of the Coterie, there were reviewers from the circles of the "Biblioteka Warszawska", who in turn, at times, forcibly diminished the value of the clergyman's works. Kraszewski saw the reasons for this difference of opinion in the influence of different philosophical currents on the Warsaw and Vilnius communities (Struve 1880: 293). Apart from that, he noticed that Jankowski did not have the courage to leave the boundaries of his inner circle:

The tight circle he mingled with, extended only by reading and knowledge of the world, which was, so to say, second-hand, may have contributed to narrowing the horizon of his artistic creations. He knew almost only what he loved and what he grew together with. He took little effort to look out into a bigger world, full of diversities. Between Vilnius, Żyrowice, Minsk, and Białynicze passed his whole life, which however, desired nothing but what surrounded it. The house of the Czudowskis, and later of Pusłowski were almost the only ones where he stayed for a short time. Likewise, in his novels and humoresques he did not venture beyond the known areas (Kraszewski 1873: 311).

In any case, it established Placyd's position as a regional writer. His artistic work was not so much a universal object to raise interest in readers from outside the Vilnius area. The writer kept in touch mostly with members of the Lithuanian literary community, publishing his books in Vilnius..$^{10}$ Also due to his style, language, and even the issues tackled, he was giving his Borderlands readers a possibility to identify with what they considered more 'homely' literary work (Charkiewicz 1928: 67). As a result, the circle of his recipients was significantly limited.

8 It is visible in the number of Janowski's publications. In the first half of the decade, fourteen of his books have appeared (two of which were translations, and one a reissue), but the second half brought us only seven new titles (three of which being translations). In the'50s, only five books were published (including one reissue).

9 Comparison to Stern is not accidental - Placyd Jankowski was inspired by English literature, among others Laurence Stern himself and Walter Scott. He also translated a few works by William Shakespeare, m.in. The Merry Wives of Windsor (1842), The Midnight Hour (1845), and Henry V (1873 - post mortem edition).

10 With merely few exceptions: Doktor Panteusz w przemianach (Leipzig 1845, Brussels 1862), Nowe opowiadania (Leipzig 1847), Fanaberie pana starosty Kaniowskiego (Warsaw 1873 - post mortem edition). 
As already mentioned, Jankowski is a person who arouses very ambivalent feelings. On the one hand, he was a renegade, who put his hand to the Russification of Greek Orthodox priests. On the other hand, a writer who was accepted and valued in the Polish literary community even after the act of apostasy. An original creator who did not adhere to the convention, inspired by Stern, Walter Scott and Shakespeare, who repeatedly published books not appealing to the tastes of critics. It was the originality and cheerful content of his works that ensured his readers' great interest, which, however, was not enough to make his texts memorable.

\section{4 / CONCLUSIONS}

Memes connected with the work of Placyd Jankowski did not survive the test of time. They did not present any universal content - seminal or sublime - and thus did not arouse the need for meme reproduction. With time, the author's originality was also obliterated, the next generations of readers had access to a larger number of memes, which effectively replaced the work of the author of Autopopobiografia. A factor which may have evoked aversion was the writer's activities regarding Russification. As mentioned above, a meme has a greater chance of survival when it adequately affects the imagination and feelings of the recipient, not only in an individual but also in a collective context. In his works, Jankowski limited himself to describing his closest surroundings, to idyll and irony, which could appeal to individuals with a specific sense of aesthetics. He did not touch upon important topics that could have a wider impact. The light humoresque, additionally given in such a form as Chaos or Pisma przed-ślubne i przed-splinowe, was a casual reading for the readers, which allowed them to take a break from the everyday life created by the governments of the partitioners. So, is there any place in the contemporary literary discourse to recall the works of Placyd Jankowski?

The fact that the meme was supplanted in some specific circumstances by others, more up-to-date at that time, does not mean that it is not valuable enough to deserve to be re-examined in changed circumstances. Placyd Jankowski, as Walerian Charkiewicz mentioned, fell victim to the weakness of his character, which was reflected not only in the subject matter of his work but also in the decisions made during his lifetime. In 1888, Aleksander Walicki, in turn, noted: "The time has yet not come to justly evaluate that beautiful character. It requires the removal of all passionate attitudes and, most of all, being able to perform a deep and subtle mental diagnosis" (Walicki 1888: 470). We can analyze Jankowski's work, without taking into account the events from his life that compromised him, as well as those attributed to him but not involving him, all the more so because his works aroused enough interest among critics due to their originality and distinctiveness from the tendencies in the Polish literature at the time. Thus, they can enrich our knowledge about the Romantic period.

\section{THE FORGOTTEN MEME. ON THE EXAMPLE OF LIFE AND WORKS OF PLACYD JANKOWSKI}

Summary Patryk Chłopek, MA, a graduate of Polish philology (editorial and publishing specialization) at the Nicolaus Copernicus University, PhD student at the Academia Artium Humaniorum in Toruń. In his doctoral dissertation, 
written under the supervision of $\mathrm{dr}$ hab. Magdalena Bizior-Dombrowska, prof. of NCU, develops the issue of the life and work of Placyd Jankowski. He also associates his research interests with the concept of memetics, typography, book market on polish lands in the $19^{\text {th }}$ century, and scientific editing

\section{ZAPOMNIANY MEM. NA PRZYKŁADZIE ŻYCIA I TWÓRCZOŚCI PLACYDA JANKOWSKIEGO}

Streszczenie Placyd Jankowski (John of Dycalp) był pisarzem działającym w latach 40. XIX wieku, szybko zdobył popularność dzięki swoim humorystycznym tekstom, lecz jeszcze przed swoją śmiercią w 1872 roku został niemalże zapomniany przez czytelników. Rodzi to pytania dotyczące reguł rządzących pamięcią kulturową. Jedną z koncepcji, którą można tłumaczyć proces dziedziczności kulturowej, jest zaproponowana przez Richarda Dawkinsa teoria memetyczna. Badacz zakłada istnienie podlegających procesowi ewolucji jednostek kultury, nazwanych przez niego memami. Ich sukces i przetrwanie zależą od posiadania konkretnych cech, na które ludzki umysł jest szczególnie podatny, tj. aktualności, oryginalności, narracyjności oraz uniwersalności. Korzystając z narzędzi wypracowanych przez memetyków, w artykule zostanie podjęta próba opisu powodów społecznego zapominania na przykładzie życia i twórczości Placyda Jankowskiego.

\section{REFERENCES}

I Blackmore S., 1999, The Meme Machine, Poznań.

I Borkowski W. - Nowak A., 2005, Wpływ społeczny jako model rozprzestrzeniania się memów, „Teksty z Ulicy. Zeszyt Memetyczny”, 9, p. 47.

I Brodie R., 2009, Virus of the Mind, Carlsbad.

I Charkiewicz W., 1928, Placyd Jankowski (John of Dycalp). Życie i twórczość, Wilno.

I Dawkins R., 2006, The Selfish Gene, Oxford.

I Dunbar R., 1996, Gooming, Gossip and the Ecolution of Language, Cambridge.

I Grant G. M., 2005, Leksykon memetyczny, tłum. J. Polakowska, ed. D. Wężowicz-Ziółkowska, „Teksty z Ulicy. Zeszyt Memetyczny”, 9, p. 73.

I Jankowski P., 1835, Chaos, Vilnius.

I Jankowski P., 1841, Pisma przed-ślubne i przed-splinowe, vol. 1-2, Vilnius.

I Jankowski P., 1843, Pamiętnik elfa, vol. 1-2, Vilnius.

I Kaczmarzyk M., 2018, Szkoła memów. W stronę dydaktyki ewolucyjnej, Gliwice.

I Kostkiewiczowa T., 2005, Tekst I, Słownik terminów literackich, ed. M. Głowiński et al., Wrocław-Warsow-Cracow, pp. 574-575.

I Kraszewski J. I., 1873, Placyd Jankowski (John of Dycalp). Wspomnienie, „Tygodnik Ilustrowany", 285-286, p. 293.

I Kraszewski J. I. - Jankowski P., 1843, Powieśćskładana, Vilnius.

I Mironowicz A., 2005, Wpływ wyznań na kształtowanie się świadomości narodowej mieszkańców Białorusi w XIX wieku, „Białoruskie Zeszyty Historyczne”, 23, p. 13. 
I Struve H., 1880, J. I. Kraszewski w stosunku do filozoficznych dążności swego czasu, Książka jubileuszowa dla uczczenia pięćdziesięcioletniéj działalności literackiej J. I. Kraszewskiego, ed. J. Unger, Warszawa, p. 293.

I Tarnowski S., 1888, (rev.: P. Chmielowski), Józef Ignacy Kraszewski: Zarys biograficzno-literacki, „Przegląd Polski”, 89, p. 586.

I Walicki A., 1888, Ks. Placyd Jankowski (John of Dycalp), „Świat”, 20, pp. 470-471.

I Wężowicz-Ziółkowska D., 2015, Antropologia a „darwinizm kosmiczny”. Pytania o zmianę paradygmatu, „Zeszyty Etnologii Wroctawskiej”, 1, pp. 138-149. 